\title{
Bladder Squamous Cell Carcinoma
}

National Cancer Institute

\section{Source}

National Cancer Institute. Bladder Squamous Cell Carcinoma. NCI Thesaurus. Code C4031.

A squamous cell carcinoma of the bladder arising from metaplastic epithelium. It represents less than 10\% of bladder carcinomas. The exception is the Middle East along the Nile Valley, where it represents the most common form of carcinoma because of the endemic nature of schistosomiasis. Bladder squamous cell carcinoma is often associated with long-standing chronic inflammation of the bladder and usually has a poor prognosis. The diagnosis of squamous cell carcinoma of the bladder should be reserved for those tumors that are predominantly keratin forming. 